\title{
THE SPECIALIZATION INSTITUTE IN DENTISTRY FROM BUCHAREST: 1928-1948
}

\author{
MIHAI BURLIBAȘA ${ }^{1}$, MĂDĂLINA VIOLETA PERIEANU ${ }^{2}$, CLAUDIA-CAMELIA BURCEA ${ }^{3}$, \\ RADU COSTEA ${ }^{4}$, VIOREL STEFAN PERIEANU ${ }^{5}$, CAMELIA IONESCU ${ }^{6}$, IULIANA BABIUC ${ }^{7}$, \\ IOANA-CRISTINA NEAGOE ${ }^{8}$, RALUCA COSTEA ${ }^{9}$, AUGUSTIN MIHAI ${ }^{10}$, MAGDALENA \\ NATALIA DINA ${ }^{11}$, MĂDĂLINA ADRIANA MALIȚA ${ }^{12}$, GABRIELA TĂNASE ${ }^{13}$, ELENA- \\ CRISTINA MARCOV ${ }^{14}$, MIHAELA CHIRILA ${ }^{15}$
}

1,2,3,4,5,6,7,10,11,12,13,14,15 “Carol Davila” University of Medicine of Pharmacy Bucharest, Romania, ${ }^{8}$ University of Pitești, ${ }^{9}$ Dental Practice Brașov

Keywords: Specialization Institute in Dentistry, Dental Clinic, Prof. Dr. Dan Theodorecu
Abstract: The Specialization Institute in Dentistry (Dental Clinic), both the one that operated in Coltea Hospital and especially the one that operated in Colentina Hospital, both in Bucharest, the capital of Romania, were the first such higher education units in dentistry from Romania, they are in fact the vanguard of the future faculties of dentistry established in our country according to the Soviet model, in 1948. Thus, in this material we tried to highlight some of the most important moments in the existence of those reference units of dental education, period 1928-1948.

\section{INTRODUCTION}

Dentistry in Romania did not exist as an independent medical specialty until after 1948, when the first faculties of dentistry were established in our country, which functioned according to the Soviet model, in the 5 well-known university centers: Bucharest, Timișoara, Iași, Cluj-Napoca and TârguMures. Until that moment, dentists in Romania came from the general medical graduates who, subsequently, carried out a specialization in dentistry, with a duration of one or 2 years, within specialized institutes in dentistry. The most well-known such specialization institutes in dentistry in Romania were those in Bucharest and Cluj-Napoca. Next, we will talk about the Specialization Institute in Dentistry (and or the Dental Clinic), which operated in Bucharest during the interwar period, and shortly after the end of World War II: two very interesting decades of the extremely troubled existence of the Romanian people, 1928-1948. But, before actually moving on to the description of what this Specialization Institute in Dentistry (Dental Clinic) in Bucharest meant, it must still be clarified, what actually meant dentistry in Romania at that time, in two very difficult decades in the history of Romania.

\section{GENERAL DATA}

An important role in the development of dentistry in Romania was played by the Law of the Ministry of Health, Labor and Social Protection of 1923, which provided that in addition to all medical faculties in the country to function a department of dentistry for general medical education and an Institute of Dentistry for the specialization of doctors in dental art.(1-4)

Thus, following the entry into force of the aforementioned law, 6 years later, in 1929, at Colţea Hospital in Bucharest, the first Specialization Institute in Dentistry was established under the administration of Board of Civil Hospitals (Romanian: Eforia Spitalelor Civile) and the Faculty of
Medicine within the University of Bucharest (known as the Dental Institute, the Institute of Dentistry or the Dental Clinic) chaired by Prof. Dr. Mina Minovici. This institute was divided into three sections, as follows:(1-4)

- a department of dental pathology and therapeutics, led by Associate Professor Dr. C. Dimitrescu, who also taught dentistry at the Faculty of Medicine, University of Bucharest;

a maxillofacial surgery department, under the leadership of Assoc. Prof. Dr. N. Sebastian;

a department of oral and dental restorative prosthetics and maxillofacial orthopedics, led by Assoc. Prof. Dr. Evloghie Staicovici.

But, it should be noted an extremely interesting aspect, namely that this Specialization Institute of Dentistry (Dental Clinic) at Colțea Hospital in Bucharest, although it operated within the Board of Civil Hospitals, was staffed by teachers from the Central Military Hospital, a very valuable medical center, with great surgical experience, as a result of wounds and oral-maxillofacial injuries treated during the First World War (both Associate Professor Dr. C. Dimitrescu and Assoc. Prof. Dr. N. Sebastian and Assoc. Dr. Evloghie Staicovici, were dental officers, who were enlisted in the Romanian Army during the First World War -1916-1918).(1-5)

This Specialization Institute in Dentistry in the country's capital Bucharest, and which operated within the Coltea Hospital, has enjoyed real success since its establishment, both by graduates of general medical schools who wanted to specialize in dentistry, and from the patients who were treated in this extremely interesting medical institution with a dental profile in Romania. However, the glory period of this first Specialization Institute in Dentistry (Dental Clinic) in Bucharest, is in fact confused with the activity of an exceptional professional, namely Prof. Univ. Dr. Dan Theodorescu, considered to be the founder of modern dentistry in Romania.

${ }^{4}$ Corresponding author: Radu Costea, Str. Plevnei, Nr. 19, Sector 1, Bucureşti, România, E-mail: mburlibasa@gmail.com, Phone: +40723 472632 Article received on 25.10.2020 and accepted for publication on 02.12.2020 


\section{CLINICAL ASPECTS}

The younger generations have heard of Prof. Dr. Dan Theodorescu, but, unfortunately, those who knew him no longer exist. Therefore, in the following we will try to answer some extremely pertinent questions, namely who was Prof. Dr. Dan Theodorescu and what was his role in the formation and development of modern dentistry in Romania.

Professor Dr. Dan Theodorescu was born on March 2, 1899 in the city of Tulcea. An emblematic personality of Romanian dentistry and maxillofacial surgery, he can be considered not only a school founder, but also a great visionary of the development and evolution of dental specialties.(1-6)

Assistant Professor in the Department of Topographic Anatomy and Experimental Surgery led by Prof. Dr. Thoma Ionescu and Prof. Dr. Ernest Juvara and then Assistant Professor in the Third Surgical Clinic led by another famous surgeon, namely to Prof. Dr. Amza Jianu, both departments being within the Faculty of Medicine of the University of Bucharest, Dan Theodorescu left for Vienna, the capital of Austria, in 1934, to study dentistry and maxillofacial surgery, under another famous master, namely Prof. Dr. Hans Pichler, considered to be the creator of oncological and orthognathic surgery in Europe (110). The great Romanian doctor was guided to do this specialization in dentistry by another famous surgeon of the time, and here we are talking about Prof. Dr. I. Iacobovici, a remarkable personality of Romanian medicine from the first half of the twentieth century.(1-6) The school in Vienna was recognized at that time not only in Europe but also worldwide, any specialist considering that an internship at the Clinic of Oral and Maxillofacial Surgery, Faculty of Medicine of the University of Vienna, Austria, led by Prof. Dr. Hans Pichler, was not only mandatory, but also a business card, which honors Prof. Dr. Dan Theodorescu, who practically managed to enrich in one year not only his knowledge in dentistry, but also those in maxillofacial surgery.(1-6)

Specifically, Dr. Dan Theodorescu was noticed by Prof. Dr. Pichler, with whom he remained friends and corresponded until the last months of his life. His knowledge of operative medicine impressed Prof. Dr. Hans Pichler, who trained Dr. Dan Theodorescu in clinical activity from the first weeks of his internship, considering him in certain fields not just a doctor who came to specialize, but also a colleague with whom he had peer-to-peer discussions.(1-6)

Returned in the country in 1936, Dr. Dan Theodorescu was appointed Associate Professor by competition in the Department of Dentistry of the Faculty of Medicine (Higher Education of Dentistry), University of Bucharest, which operated within the Specialization Institute in Dentistry (Dental Clinic) of Coltea Hospital in the country's capital, Bucharest, a health institution under the administration of Board of Civil Hospitals and the Faculty of Medicine.(1-6) Next, in 1937, Dr. Dan Theodorescu became an associate professor in the Department of Oral Restorative Prosthesis and Maxillofacial Orthopedics, post released by retirement of Assoc. Prof. Dr. Evloghie Staicovici.(1-6)

From the very beginning, Assoc. Prof. Dr. Dan Theodorescu did not hesitate to surround himself with young doctors, collaborating at the same time with specialists in dentistry trained by other schools, all with the aim of organizing specialization courses in dentistry for medical graduates which were beginning to differ from the old dentists.(1-6) But, in 1939, Dr. Dan Theodorescu took the position of university professor by competition, but he also became head of the Department of Dentistry (Higher Education of Dentistry) of the Faculty of Medicine, University of Bucharest, whose courses and practical work were mandatory at that time.(1-6) Next, Prof. Dr. Dan Theodorescu took over the management of the Specialization Institute in Dentistry [or the Institute of Dentistry (Dental
Clinic), as it was also known at that time], from Coltea Hospital, he reorganized it, imprinting to dentistry the surgical character and, at the same time, developing scientific research at European level. In gratitude to his master, Prof. Dr. I. Iacobovici, who advised him to specialize in dentistry at the best European center of that period, Oral and Maxillofacial Surgery Clinic of the Faculty of Medicine, University of Vienna, Austria, under the leadership of Prof. Dr. Hans Pichler, Prof. Dr. Dan Theodorescu founded in 1937 the Romanian Journal of Dentistry and in 1938 the Romanian Society of Dentistry, where Prof. Dr. I. Iacobovici was elected president of honour.(1-6)

Another interesting aspect that we want to mention in this paper is the one related to the fact that, on August 27 , respectively 30,1940 , as a sign of appreciation for the activity of Prof. Dr. Dan Theodorescu, Krupp Plants in Essen (more precisely, the company FRIEDRICH KRUPP AKTIENGESELLSCHAFT based in Essen, Germany), made a really impressive donation to the Specialization Institute in Dentistry (Dental Clinic), within the Colțea Hospital in Bucharest, whose director was none other than the distinguished Professor Dr. Dan Theodorescu.

In 1941, Prof. Dr. Dan Theodorescu founded at Colentina Hospital, also under the patronage of Board of Civil Hospitals and the Faculty of Medicine within the University of Bucharest, a new Specialization Institute in Dentistry (Dental Clinic). In fact, we are talking about a pavilion with 3 levels, an amphitheater, 74 beds and 60 complete dental units, as well as a dental laboratory at European level for that time. This new institute trained high-class dentists and a European-level technical training, ceramics and skeletal prostheses being performed here on a regular basis.(1-6) The graduates of this new Specialization Institute in Dentistry (Dental Clinic) within the Colentina Hospital in Bucharest, later became chief doctors in the main cities of the country, leaving in the villages only the empirically improvised dentists, occasional prosthetists, who contrasted strongly with the high level of dentists trained at this reference medical unit with a dental profile in Romania. Also, during this period, dental clinics with management staff were formed and developed in other large cities of Romania: Iaşi, Cluj-Napoca and Târgu-Mureş, where there were already medical faculties.(1-6,11-16)

At the same time, the Romanian Society of Dentistry held meetings and sessions of scientific communications at Colțea Hospital, and later at Colentina Hospital, once a month. These were meetings of real scientific debates, during which the doctors from the province presented their experience with courage and competence, meetings initially held in the amphitheater of the Specialization Institute in Dentistry (Dental Clinic) at Coltea Hospital and after 1941, in the amphitheater of the newly established Specialization Institute in Dentistry (Dental Clinic), within the Colentina Hospital in Bucharest (16). In all this scientific movement, Prof. Dr. Dan Theodorescu has established himself as a great teacher, receptive, forgiving, willing to collaborate scientifically with colleagues from Targoviste, Iasi, Braila, Ploiesti, Constanta, Brasov etc., and even from other university centers.(1-6)

Prof. Dr. Dan Theodorescu was also concerned with the development of dental care so that, in addition to specialization courses organized for doctors, he also set up a school of dental technicians within the Specialization Institute in Dentistry (Dental Clinic) (in 1943) and a school of dental nurses, his teachers being his collaborators. He was aware that quality dental care can only be provided by one team, namely: the dentist, the nurse and the dental technician.(1-6)

At the same time, we must not forget the contribution of Prof. Dr. Dan Theodorescu to the treatment of the wounded from the Second World War. In 1941 he found at the Colentina 


\section{CLINICAL ASPECTS}

Hospital a robust team, formed and trained for the care of the wounded on the Eastern Front, where the Romanian Army fought in collaboration with the German Army against Soviet Russia. This team benefited from the contribution of young, enthusiastic and promising doctors, who later formed the nucleus of the Department of Maxillofacial Surgery of the Faculty of Dentistry in Bucharest (1-6). It is especially about Dr. Cicerone Mihail and Dr. Valerian Popescu, worthy descendants of Prof. Dr. Dan Theodorescu.(1-6)

For dentists, Prof. Dr. Dan Theodorescu published in 1943 the paper entitled Anesthesia in oral surgery.(1-6) Also, the famous dentist sketched the chapters of the future maxillofacial surgery course, which he worked with his collaborators until the last months of his life. But Prof. Dr. Dan Theodorescu did not have the satisfaction of seeing it printed, this being realized only in 1955 (1-6).

A renal distress that appeared after a scarlet fever that he fell ill during his internship, marked the state of health in the last year of life of Prof. Dr. Dan Theodorescu. He died in 1948, at the age of 49 , without the satisfaction of seeing the faculties of dentistry established, where his modern biological conceptions were brought to life, in the specialty of which he left the mark of his great personality.(1-6)

Figure no. 1. a-d Oral and maxillofacial surgery treatment sheet from the Specialization Institute in Dentistry (Dental Clinic) (Collection of Assoc. Prof. Dr. Mihai Burlibașa)
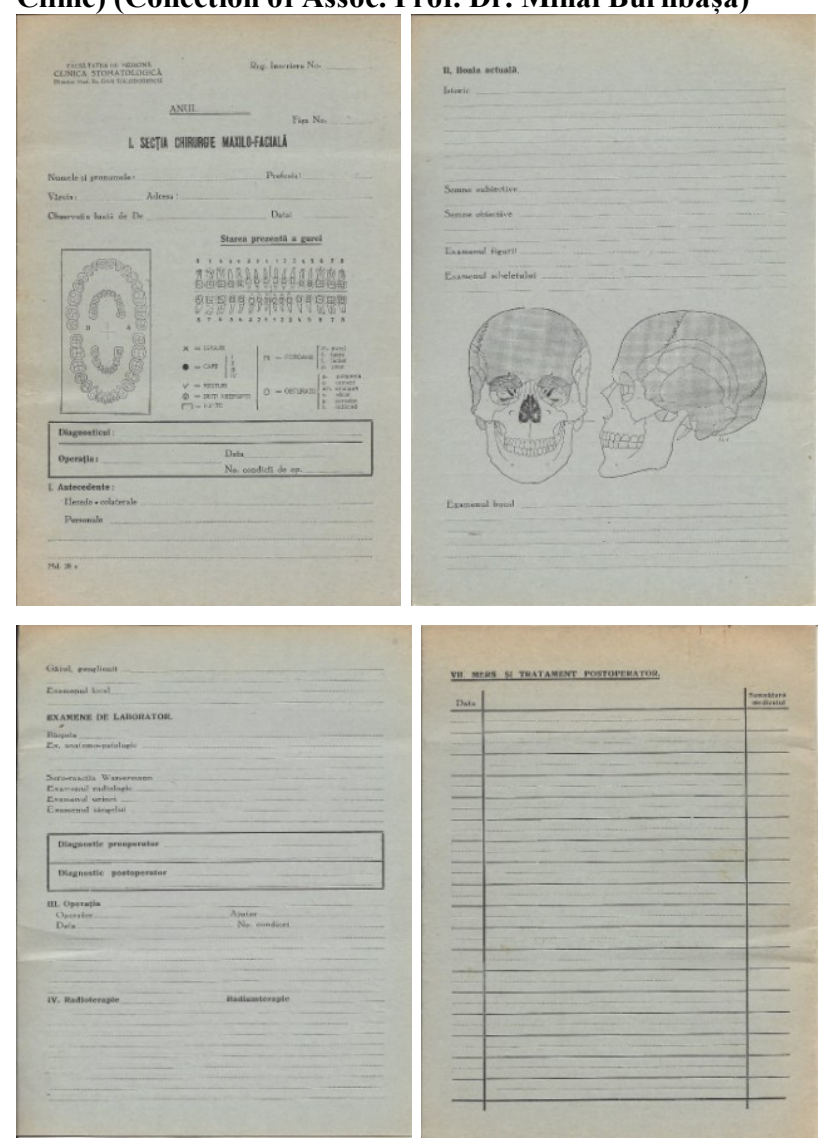

However, going back to what this new Specialization Institute in Dentistry (Dental Clinic) in Bucharest meant, which operated within the Colentina Hospital, it must be remembered that, between May 29-30, 1943, that is, in full development of the of the Second World War (1939-1945), the works of the National Congress of Dentistry took place, under the guidance of the Romanian Society of Dentistry, works attended by the most important personalities of the medical world in Romania, but also a series of guests from abroad, especially from
Germany led at that time by Adolf Hitler, but which was an ally of Romania.(1-6)

We cannot conclude this material without presenting the model of dental treatment sheet, a model that was used both in the Specialization Institute of Dentistry (Dental Clinic) at Coltea Hospital, and in the Specialization Institute in Dentistry (Dental Clinic) from Colentina Hospital, both in the capital of Romania, Bucharest, files considered revolutionary for those times (these are the file for oral and maxillofacial surgical treatment, the file for conservative treatment and the file for prosthetic treatment) (figure no. 1-3).

Figure no. 2. a-b Conservative treatment sheet from the Specialization Institute in Dentistry (Dental Clinic) (Collection Assoc. Prof. Dr. Mihai Burlibașa)

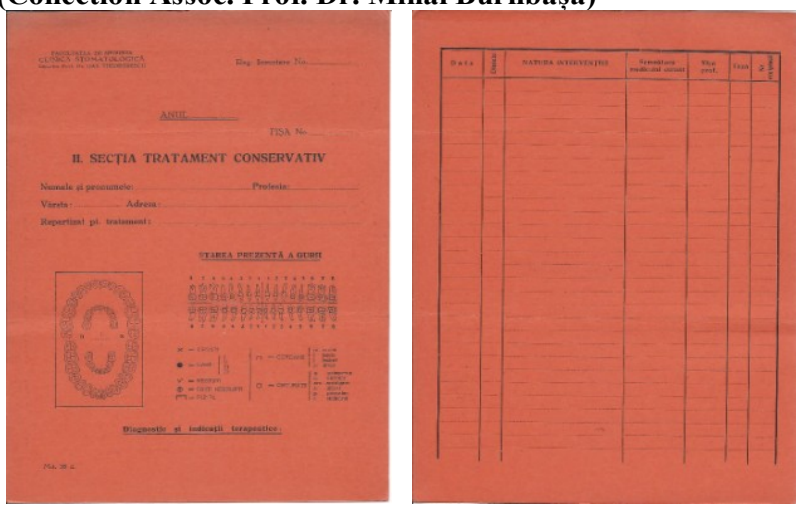

Figure no. 3. a-b Prosthetic treatment form within the Specialization Institute in Dentistry (Dental Clinic) (Collection Assoc. Prof. Dr. Mihai Burlibașa)

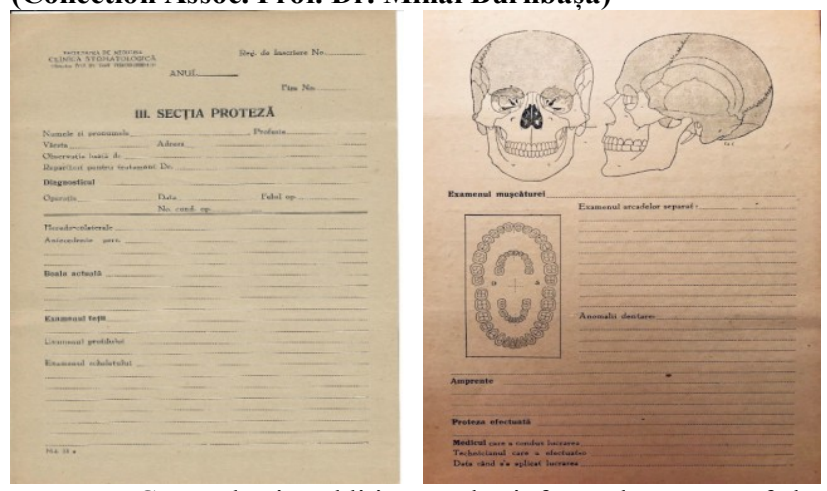

Currently, in addition to the informed consent of the patient, the dental record sheet allows the dentist to record all clinical observations on the condition of the dento-maxillary system and oral cavity, as well as other anamnestic, clinical data, complementary examinations insisting- especially on imaging (radiological) examinations, which are necessary to establish diagnoses and therapeutic indications.(1-5) But, at that moment, within the Specialization Institutes in Dentistry in Bucharest (from Colțea Hospital, respectively Colentina Hospital) we are talking about a very balanced dental treatment sheet, excellently designed, based especially on clinical and direct observation examinations, imaging examinations (radiology) being very difficult to access in the decade 19381948.(1-15)

\section{CONCLUSIONS}

The Specialization Institute in Dentistry (Dental Clinic) both the one that operated within the Coltea Hospital and especially the one that operated within the Colentina Hospital, both in Bucharest, the capital of Romania, were in fact the first such higher education units of dentistry in Romania, they 


\section{CLINICAL ASPECTS}

represent the vanguard of the future faculties of dentistry established in our country according to the Soviet model, in 1948.

Without these reference medical units with dental profile that functioned in our country until 1948, without the contribution of this extraordinary professional who was Prof. Dr. Dan Theodorescu, in Romania, a correct and quality medical act in dentistry could not have existed under no circumstances in two decades of fire for the Romanian people (1928-1948). There was a very competent guidance of future dental specialists, provided by an excellently trained teaching staff, there were scientific presentations of high quality and accuracy presented within the Romanian Society of Dentistry, but especially there was enthusiasm from this wonderful team led and excellently managed by Prof. Dr. Dan Theodorescu, qualities that today are increasingly rare, among the teaching staff of the profile faculties in Romania.

contributions.

\section{Acknowledgement}

In this article, all the authors have equal

\section{REFERENCES}

1. Burlibaşa M şi colab. Pagini din istoria stomatologiei româneşti şi universale, Ediţie adăugită şi revizuită, Editura Cermaprint, Bucureşti; 2011.

2. Burlibaşa $M$ şi colab. Pagini din istoria stomatologiei românești şi universale (vol. I), Editura Cermaprint, Bucureşti; 2008.

3. Ursea N și colab. Enciclopedia medicală românească, secolul XX, Fundaţia Română a Rinichiului, pag. 1259. 1284, Bucureşti; 2001.

4. Burlibașa M, Burlibașa L, Tănase G et al. Despre Eforia Spitalelor Civile. Rolul acesteia în formarea și dezvoltarea stomatologiei în România. În: Probleme în medicină și biologie, Vol. IX, pag. 19-164, coordonatori: Tănase G., Dina M.N., Dumitru S.G. et al., Editura Ars Docendi, București; 2019.

5. Burlibaşa M, Dumitru SG, Costea R et al. Serviciile medicale de stomatologie din cadrul armatelor combatante în timpul Primului Război Mondial (1914-1918). În: Probleme în medicină și biologie, Vol. VII, pag. 19-123, coordonatori: Burcea C.C., Dumitru S.G., Costea R. et al., Editura Ars Docendi, București; 2017.

6. Burlibașa M. Rolul Prof. Dr. Dan Theodorescu în formarea și dezvoltarea stomatologiei românești în timpul celui de-al Doilea Război Mondial. În: Progrese în medicina dentară, Vol. I, pag. 45-82, coordonatori: Trăistaru T., Burlibașa M., Editura Ars Docendi, București; 2011

7. Ionescu CA, Popovici LR, Mocuța D, Malița C, Burlibașa M. The quality of human life from the perspective of sustainable development Metalurgia International. 2009; 14:41-43.

8. Mocuța D, Popovici IA, Burlibașa L, Cristache G, Sfeatcu $\mathrm{R}$, Bodnar T. Impact of the living conditions on population health. Metalurgia International. 2009;14:17-19.

9. Mocuța D, Popovici IA, Burlibașa L, Cristache G, Sfeatcu $\mathrm{R}$, Bodnar T. Impact of the living conditions on population health. Metalurgia International. 2009;14:17-19.

10. Burlibaşa M, Muntianu L, Tănase $G$, Bucur MB, Comes $\mathrm{CA}$, Ionescu CA. Study on microbial contamination of biomaterials in medical practice. Metalurgia International. 2010; Vol. XV, Spec. Issue No. 2, p. 163-166.

11. Ispas DC, Eftene OA, Burlibașa M, Bucur MB, Tănase G, Cristache CM. Implications of titanium in orthodontics and dental facial orthopedics. Metalurgia International. 2011; Vol. XVI, Isuue No. 10, p. 72-74.

12. Tănase G, Burlibașa M, Muntianu L, Simion I, Bucur MB,
Ionescu CA. Testing the antibacterial potential of biomaterials in medical practice. Metalurgia International. 2010; Vol. XV, Spec. Issue No. 2, p. 160-162.

13. Burlibașa M, Tănase $G$, Muntianu L, Murgu AI, Teodorescu E, Malița C. Quality of life, a multidisciplinary concept with economic and social impacts in medical practice. Metalurgia International. 2010; Vol. XV, Spec. Issue No. 4, p. 88-90

14. Burlibașa M, Cernușcă-Mițariu M, Burcea CC, Mițariu M, Ferechide D. Halogen compounds - theoretical, physiological and practical aspects regarding the decontamination, disinfection and sterilisation of intsruments and biomaterials in dental medicine practice. Metalurgia International. 2012; Vol. XVIII, Spec. Issue No. 3, p. 54-57.

15. Burlibașa M, Cernușcă-Mițariu M, Cernușcă-Mițariu S, Mițariu M, Malița M. Theoretical and practical aspects related to biomaterials decontamination in dental medicine (with reference to dental prosthetics). Metalurgia International. 2013; Vol. XVIII, No. 4, p. 261-267.

16. Eșian D, Man A, Burlibașa L, Burlibașa M, Perieanu MV, Bică C. Salivary level of Streptococcus mutans and Lactobacillus spp. related to a high risk of caries disease. Rom Biotechnol Lett. 2017; Vol. 22, No. 2, p. 1249612503 . 